\title{
The impact of HR issues in retail sector in emerging market with special reference to lucknow.
}

\author{
Neeta Bhatla, KrishanKantPandey \\ Research Scholar,BBDNIIT \\ Astt Professor,BBDNIIT
}

\begin{abstract}
Successful organizations to sustain and compete in the global market place require talented qualified global managers.. An analysis of human resources issues is essential for retail sector. In order to develop, train, retain and cultivate the human resource to meet the demands of the global environment .Attraction, retention, knowledgeable human resources are required to meet the demands of the complex global environment .This paper highlight the effects of organizational culture on retail sector, workforce diversity in the retail sector,competency profiles of retail professionals. Identification of talent to prepare the skilled professionals for today. The paper also brings out the historic perspective of retail positions (i.e. managers with operation and functional orientation) human resource managers are modifying and updating profiles of the retail managers position to encompass political, cultural, social network and an awareness of significant differences to be found in global markets. The paper also focuses on the current practices adopted by human resource for retail sector. The study was carried in organized retail sector i.e. shopping malls of lucknow. A research was administered on 50 executives in the retail sector. The paper will bring the strategies the human resource should adopt which will help to cultivate, train and develop the competent workforce of today.
\end{abstract}

Key words: Organized Retailing, Human resources, unorganized retailing

\section{Introduction}

Retail is currently the booming sector of the Indian economy. This trend is expected to continue uninterrupted for at least the next two-three decades, attracting huge attention from all quarters of the economy entrepreneurs, business heads, investors as well as real estate owners and builders-. Retail sector is also expected to create huge employment as it will expand across the country at a massive scale. The reasons for this expansion of retail is evidently related to the liberalization and opening up of the Indian economy which had immense effects on the consumer demand, tastes and preferences as well as the buying capacities of the Indians (specially the growing middle class) over the past few years. Slowly and steadily retail has witnessed considerable growth while a new form of organized retail sector has emerged within the retail industry. Stated simply, it refers to the organized retail chains managed by big corporate houses such as the Pantaloons group, $\mathrm{K}$. Raheja group, the Piramals and so on.

Retail market in India is expected to grow from US $\$ 350$ billion to US $\$ 427$ billion by 2010.1 Retail has traditionally been a major sector in India employing millions of people. Retailing currently contributes $10 \%$ of India's GDP and 6-7\% of employment (Kalhan,2007). The popular traditional form of retail has been the socalled 'unorganized' form of retailing mostly represented by small family-owned stores, selling one particular category of product, e.g Kirana shops, drug stores, located in the market place or residential areas, road-side stalls, hand-cart and pavement vendors etc. However with the opening up of theIndian economy since 1991 retail sector has gradually undergone considerable changes in its form. Though earlier mainly represented by the low-cost 'mom-and-pop' store format, retail today is emerging has a huge "industry". The major shift has been the emergence of an organized sector within the retail industry.In common parlance organized sector usually denotes unionization. However, in the Indian context organized sector is differentiated from unorganized sector in terms of employment status. The former offers regular contractual hired employment along with social security benefits and hence implies better service conditions for its employees as opposed to their counterparts in the unorganized sector. Retail in India used to fall largely into the unorganized category. However, recently there has been the emergence of organized sector within retail. Though organized retail currently forms a very miniscule proportion of the entire retail sector in India (around 3\%), by 2010 it is expected to be expanding at a considerable rate (compound annual growth of $40 \%$ ). According to a report released by FICCI (Federation of Indian Chambers of Commerce and Industry), the organized retail is likely to increase its share to over $20 \%$ by 2010. Organized retail occupied a space of 1 million sq. ft. in 2002, which shot up to nearly 14 million sq. ft. by 
2007 and in 2008 the figure is expected to be 16 million sq.ft. India Retail Report, 2007 forecasts that 2.2 million jobs will be created in this new retail sector by 2010 .

"The Geography of Opportunity - The India 50" (June, 2007) has also identified 50 Indian cities which are the potential beneficiary of the organised retail boom. These have been divided into five categories:

a. Maturing-Delhi, National Capital Region (NCR), Mumbai belong in this category

and these markets are seeing saturation. However large one-stop malls having retail,

entertainment, food and hospitality would have demand, along with hypermarkets, and

malls

b. Transitional- These include cities like Bangalore, Kolkata, Hyderabad, Pune, Chennai and Ahmedabad. By 2008, they would account for one-third of total market due to their large corporate sectors, high level of economic activity, above-average income and large middle class.

c. High-Growth- These are the 'next' retail destinations of Chandigarh, Jaipur, Ludhiana, Lucknow, Kochi, Surat and Vadodara.

d. Emerging-They include cities which are tourist oriented, and have setup infrastructure for IT companies like Nagpur, Indore, Nasik, Bhubaneshwar, Vizag, Coimbatore, Mangalore, Mysore, Thiruvananthapuram, Amritsar, Agra and Goa.

e. Nascent- These offer the first-mover advantage as the income levels and corporate activities are limited. The cities are Patna, Bhopal, Meerut, Asansol, Varanasi, Kolhapur and Sonepat. The top 15 cities in the list will contribute more than 80 per cent of the total national retail business by 2008

Currently the most popular organized retail formats are the following:

i. Malls: Shopping malls are the largest form of organized retailing today. These are located mainly in metropolitan cities, in proximity to urban outskirts. The area of shopping malls ranges from 60,000 sq $\mathrm{ft}$ to 7,00,000 sq $\mathrm{ft}$ and above. The idea is to lend an ideal 'shopping experience' which includes an amalgamation of product, service and entertainment all under a common roof. Examples include Inorbit Mall in Mumbai, Ansal Plaza in Delhi, South City mall in Kolkata

ii. Specialty Stores: these are stores that focus on specific market segments, specializing on particular products such as entertainment and recreation products, gift items and so on. The most notable among these include chains such as the Bangalore based Kids Kemp, the Mumbai books retailer Crossword, Times Group's music chain Planet M.

iii. Discount Stores: As the name suggests, discount stores or factory outlets, offer discounts on the MRP through selling in bulk reaching economies of scale or excess stock left over at the season. The product category range includes variety of perishable/ non perishable goods.

iv. Department Stores: Large stores ranging from 20000-50000 sq. $\mathrm{ft}$, catering to a variety of consumer needs. These include localized departments such as clothing, toys, home, groceries, etc. the popular among these are Big Bazaar, DMart etc.

v. Hypermarkets/Supermarkets: Large self service outlets, having a strong focus on food \& grocery and personal sales are termed as Supermarkets. Super Markets can further be classified into mini supermarkets typically $1,000 \mathrm{sq} \mathrm{ft} \mathrm{to} 2,000 \mathrm{sq} \mathrm{ft}$ and large supermarkets ranging from of $3,500 \mathrm{sq} \mathrm{ft}$ to 5,000 sq. ft. These stores today contribute to $30 \%$ of all food \& grocery organized retail sales. Examples are Foodland Fresh, Haiko, Shoprite etc.

vi. Convenience Stores: These are relatively small stores (400-2,000 sq. feet) usually located near residential areas. They stock a limited range of high-turnover convenience products and are usually open for extended periods during the day, seven days a week. Prices are slightly higher due to the convenience premium.

vii. MBO's: Multi Brand outlets, also known as Category Killers, offer several brands across a single product category. These usually do well in busy market places and metropolitan cities.

\section{Literature Review}

Research from Global Hunt India (2009) shows sector-wise analysis that is BPO, ITeS and aviation sectors will witness attrition level of as much as 40-45 per cent this year, followed by retail and telecom (35-40 per cent), IT (30 per cent), pharma and infrastructure (20-25 per cent), while research and development will see 15-20 per cent of attrition. The Indian retail market, which is the fifth largest retail destination globally, has been ranked as the most attractive emerging market for investment in the retail sector (AT Kearney's 2009). In 2007, the retail trade in India had a share of $8-10 \%$ in the GDP (Gross Domestic Product) of the country. In 2009, it rose to $12 \%$. It is also expected to reach $22 \%$ by 2010 .

Among the 500 top retailers in Asia-Pacific 17 Indian retailers mark their position, as against 87 from China, 72 from Japan, 48 each from Korea and Taiwan, 40 from Australia, 38 from Hong Kong and 31 from Singapore (Retail Asia July 2008). According to the Compare Infobase Limited, 2007, almost all the sectors in India are facing attrition, but the reasons and effects are unique to each sector like $50 \%$ in retail sector, $50 \%$ 
The impact of HR issues in retail sector in emerging market with special reference to lucknow.

BPO sector, aviation 46\%, telecom 30\%, financial 40\%, FMCG 17\%, manufacturing, biotechnology $35 \%$, pharmaceuticals $32 \%$ (Niketh S 2008)

The no. 1 reason for this growing attrition rate is compensation unfairness. $21 \%$ of the organizations who took part in the survey said that their employee left the organization because they got offers from other organizations offering better pay packages. The no. 2 reason was less growth opportunities and no. 3 reason was role stagnation (Hewitt's 2006).Lynn (1997) beli responsibilities, opportunities and other details to reduce the chances of making hiring mistakes.In a study of retail salespeople (Firth et al, 2003) found that job stressors (example work overload, job ambiguity) are the factors that trigger the chain of psychological states that lead to intention to quit. They suggested that supervisor support can reduce the impact of stressors on psychological states and intentions to quit. Monitoring workloads and supervisor-subordinate relationships by management may not only reduce stress but increase job satisfaction and commitment to the organization. The first reason why losing good employees is costly is that the investment in training is significant and that cost is spread out over the course of the trainee's employment. Training can help revitalize personnel. For an increasing number of people, the chance to learn new skills is a significant personal goal for both the careeropportunities education can provide and for the chance to do something a little different (Mendonsa, 1998).Employees want more interaction with management, more self-satisfaction on the job, more responsibility and more control over decisions affecting them. Theywant their work to make a difference and want to be part of something that matters (Taylor, 1997).

Mobley et al (1979) concluded that a number of studies offered moderate support for a negative relationship between satisfaction with supervision andturnover (i.e. the higher the satisfaction with supervision, the lower the turnover). Lee \& Corey (1995) stated that SCM consists of the integration activities taking place among a network of facilities that procure raw material, transform them into intermediate goods and then final products, \& deliver products to customers through a distribution system. Giunipero et.al. (2008) in a recent literature review of a decade of SCM literature note that the literature, in reality, is still very fragmented and although several studies purport to discuss supply chain issues, most of the existing research only examines one link of the chain, or more importantly only focuses on one ingredient in the supply chain performance mix. The impact of human resource management (HRM) policies and practices on firms performance is an important topic in the field of human resource management, industrial relations, and industrial and organisational psychology (Boudreau 1991, Jones \& Wright 1992, Kleiner 1990). A number of texts have appeared in recent years promoting the advantages of using high involvement human resource practices (Arthur 1994, Kochan\&Osterman, 1994, Levine 1995, Pfeffer 1998, Guthurie 2001) as well as on the use of High Performance Work Practices, which can improve the knowledge, skills, and abilities of a firm's current and potential employees, increase their motivation, reduce shirking, and enhance retention of quality employees (Jones \& Wright 1992).Retailers achieve their financial objectives by effectively managing their five crucial resources: their location, merchandise inventory, stores, employees and customers. Human Resource Management (HRM) is particularly vital in retail sector as they are labour intensive like service sector. HRM can be the basis of a sustainable competitive advantage for the following three reasons. First, labour cost accounts for a significant percentage of retailer's total expenses. Thus, effective management of employees can result in cost advantage. Second, the experience that most customers have with a retailer is determined by the activities of employees who select merchandise; provide information and assistance and stock display and shelves. Thus, organisation's talent plays a major role in differentiating a retailer's offering from its competitors offering. Finally, the potential advantages are difficult to duplicate.

Retailing is human resource-centered. It is estimated that in India up to 95 million square feet of retail space would be created by the end of 2012. Assuming one front end customer associate for every 300 square feet of retail space created India would need approximately an additional 2,10,000 customer associates in the next three years. Jobs in the organized sector includes those at the malls, discount formats ,stop over formats such as those within the petrol bunks, departmental stores, brand retail chains ,specialty retailers, hypermarkets ,supermarkets in a cross section of products and services -fashion, food, grocery ,consumer durables ,FMCG , lifestyle goods etc. newer formats like cellular/mobile shops, retailing by IT voice and video applications etc. will be dominant in offering jobs in retail -especially front end sales and customer service jobs. The following table depicts the human capital and its share in organized retail. 
The impact of HR issues in retail sector in emerging market with special reference to lucknow.

TABLE 1: HUMAN CAPITAL IN ORGANIZED RETAIL (\% SHARE)

\begin{tabular}{|l|l|}
\hline Retail forms & Percentage share \\
\hline Food \& grocery & $17 \%$ \\
\hline Beauty \& body care & $3.56 \%$ \\
\hline Books, music \& gifts & $13.08 \%$ \\
\hline Pharmacies & $2 \%$ \\
\hline Jewellery\& watch & $10 \%$ \\
\hline Footwear & $32.84 \%$ \\
\hline Clothing \& textile & $36 \%$ \\
\hline Home décor \& furnishing & $8.76 \%$ \\
\hline Consumer durables & $17.04 \%$ \\
\hline
\end{tabular}

Source: http://www.docstoc.com/docs/27855682/An analysis of Indian retail industry

\section{Research Methodology}

The research was descriptive in nature and uses convenience sampling. The sample size is 50 . The source of data collection was primary and secondary. Primary data was collected from retail stores which includes the following:

\begin{tabular}{|l|l|}
\hline S.no & Name of the retailer \\
\hline 1 & Pantloon \\
\hline 2 & Shopper stop \\
\hline 3 & Spencer \\
\hline 4 & Moms and pops store \\
\hline 5 & Globus \\
\hline
\end{tabular}

Secondary data was collected from the past data, reportspublished, journals. The data analysis was done with using the statistical tools.

\section{Research Objectives}

The research objectives are follows:

1. To study the impact of human resource issues inretail sector in emerging markets with special to lucknow.

2. To study the skills requirements for executives in retail sector with special reference tolucknow.

3. To study the satisfaction of executives in retail sector with special reference tolucknow.

4. To study the retention of executives in retail sector with special reference to lucknow.

5. To suggest strategies for the human resource should adopt which will help to cultivate, train and develop the competent workforce.

\section{RESEARCH HYPOTHESIS}

1. The Skills requirements of executives in the retail industry are correlated with the competence level of the executives.

2. The retention level of the executives is correlated with the satisfaction of them.

DATA ANALYSIS AND INTERPRETATION

1. Age profile of the respondents

\begin{tabular}{|l|l|l|}
\hline S.no & Age profile of the executives & No of executives \\
\hline 1 & Below 25 years & 10 \\
\hline 2 & 25 years-30 years & 15 \\
\hline 3 & 31 years-40 years & 20 \\
\hline 4 & 41 years- 50 years & 05 \\
\hline
\end{tabular}

2 Skills requirements of the executives

\begin{tabular}{|l|l|l|}
\hline S.no & Skills requirements & No of executives \\
\hline 1 & excellent communication and interpersonal skills & 05 \\
\hline 2 & Ability to work under pressure and tight deadlines & 05 \\
\hline 3 & Leadership and management qualities & 05 \\
\hline 4 & Flexibility & 02 \\
\hline 5 & Analyzing and problem solving & 03 \\
\hline 6 & All of the above & 30 \\
\hline
\end{tabular}


3 Satisfaction level of the executives

\begin{tabular}{|l|l|l|}
\hline S.no & Satisfaction level of executives & No of executives \\
\hline 1 & Below $50 \%$ & 05 \\
\hline 2 & $50 \%-75 \%$ & 20 \\
\hline 3 & $75 \%-100 \%$ & 15 \\
\hline 4 & $100 \%$ & 10 \\
\hline
\end{tabular}

4 Salary profile of the executives

\begin{tabular}{|l|l|l|}
\hline S.no & Salary profile of executives & No of executives \\
\hline 1 & Below 20,000 & 05 \\
\hline 2 & $20,000-30,000$ & 10 \\
\hline 3 & $30,000-40,000$ & 15 \\
\hline 4 & $40,000-50,000$ & 10 \\
\hline 5 & Above 50,000 & 10 \\
\hline
\end{tabular}

5 How long are you associated with the organization?

\begin{tabular}{|l|l|l|}
\hline S.no & Association with the organization & No of executives \\
\hline 1 & 2 years & 10 \\
\hline 2 & $3-5$ years & 15 \\
\hline 3 & $5-7$ years & 10 \\
\hline 4 & $8-10$ yers & 10 \\
\hline 5 & Above 10 years & 05 \\
\hline
\end{tabular}

6. Competency profile of executives.

\begin{tabular}{|l|l|l|}
\hline S.no & Key competencies & No of executives \\
\hline 1 & Global business leadership & 05 \\
\hline 2 & Integrated business planning & 10 \\
\hline 3 & $\begin{array}{l}\text { Integrated value chain } \\
\text { implementation }\end{array}$ & 05 \\
\hline 4 & Transformational capabilities & 10 \\
\hline 5 & All of the above & 20 \\
\hline
\end{tabular}

6. Retention level of executives

\begin{tabular}{|l|l|l|}
\hline S.no & & No of executives \\
\hline 1 & Below $30 \%$ & 30 \\
\hline 2 & $31 \%-50 \%$ & 12 \\
\hline 3 & $51 \%-70 \%$ & 05 \\
\hline 4 & $71 \%-100 \%$ & 03 \\
\hline
\end{tabular}

\section{Analysis of Hypothesis}

1. The Skills requirements of executives in the retail industry are correlated with the competence level of the executives.

\begin{tabular}{|l|r|r|r|}
\multicolumn{5}{|c|}{ Descriptive Statistics } \\
\hline & Mean & Std. Deviation & $\mathrm{N}$ \\
\hline competencies & 8.3333 & 6.83130 & 6 \\
skills & 8.3333 & 10.68956 & 6 \\
\hline
\end{tabular}

\begin{tabular}{|c|c|c|c|}
\hline \multicolumn{4}{|c|}{ Correlations $^{\mathrm{a}}$} \\
\hline & & competencies & skills \\
\hline \multirow[t]{4}{*}{ competencies } & Pearson Correlation & 1 & -.648 \\
\hline & Sig. (1-tailed) & & .082 \\
\hline & $\begin{array}{l}\text { Sum of Squares and Cross- } \\
\text { products }\end{array}$ & & -236.667 \\
\hline & Covariance & 46.667 & -47.333 \\
\hline \multirow[t]{4}{*}{ skills } & Pearson Correlation & -.648 & 1 \\
\hline & Sig. (1-tailed) & .082 & \\
\hline & $\begin{array}{l}\text { Sum of Squares and Cross- } \\
\text { products }\end{array}$ & -236.667 & 571.333 \\
\hline & Covariance & -47.333 & 114.267 \\
\hline
\end{tabular}

a. Listwise $\mathrm{N}=6$ 
2. The retention level of the executives is correlated with the satisfaction of them. Descriptive Statistics

\begin{tabular}{|c|c|c|c|c|}
\hline & Mean & Std. Deviation & $\mathrm{N}$ & \\
\hline Satisfaction & 12.5000 & 6.45497 & 4 & \\
\hline Retention & 12.5000 & 12.28821 & 4 & \\
\hline \multicolumn{5}{|c|}{ Correlations $^{\mathrm{a}}$} \\
\hline & & & Satisfaction & Retention \\
\hline \multirow[t]{4}{*}{ Satisfaction } & \multicolumn{2}{|c|}{ Pearson Correlation } & 1 & -.546 \\
\hline & \multicolumn{2}{|l|}{ Sig. (1-tailed) } & & .227 \\
\hline & \multicolumn{2}{|c|}{ Sum of Squares and Cross-products } & 125.000 & -130.000 \\
\hline & \multicolumn{2}{|l|}{ Covariance } & 41.667 & -43.333 \\
\hline \multirow[t]{4}{*}{ Retention } & \multicolumn{2}{|c|}{ Pearson Correlation } & -.546 & 1 \\
\hline & \multicolumn{2}{|l|}{ Sig. (1-tailed) } & .227 & \\
\hline & \multicolumn{2}{|c|}{ Sum of Squares and Cross-products } & -130.000 & 453.000 \\
\hline & \multicolumn{2}{|l|}{ Covariance } & -43.333 & 151.000 \\
\hline
\end{tabular}

a. Listwise $\mathrm{N}=$

\section{ISSUES FACING HR IN RETAIL SECTOR}

There are a number of issues involved in retail business in India which certainly impact the growth of the sector. Undoubtedly, the retail businesses need largescale hiring and staffing in the retailing is unique due to the following reasons:

$\checkmark \quad$ Retail jobs in the frontline are low paid jobs with an industry average of Rs 3000 . Hence salary paid cannot be used as motivators to induce people to applyfor jobs.

$\checkmark \quad$ Retail jobs are also not career builders in the short run. Not many of the front lines can grow to become departmental /stores head

$\checkmark \quad$ Value addition is very uncommon except in few professionally run retailing units. There is paucity in effective training imparted to the front liners.

$\checkmark \quad$ There is hardly any kind of human resource strategy devised in retailing sector. Though retailers spend a lot in incorporating international standards in totheir outlets but fail in doing the same, when it comes to human resource.

$\checkmark \quad$ Retail jobs are physically very demanding. Employees are required to work for 10hours a day, six days a week, work on weekends, holidays and festivedays.

$\checkmark \quad$ Attrition level is very high in retail sector. The attrition in the middle and senior management is not as significant as that of front end personnel; it is almost $20 \%$ in front liners. But another key issue is lack of competency in modern retailing practices.

\section{CHALLENGES FACED IN HRM IN RETAILING}

The HR managers in retail sector are currently facing the following challenges:

$\checkmark$ Managing part-time employees is the biggest challenge for an HR manager in the retail firm, as they work only during their shift and are not totally involved in their work.

$\checkmark$ Retailers operate on thin margins and hence have to be cautious in paying high wages. Paying high salaries will deprive them of good profits.

$\checkmark$ Unavailability of experienced manpower.

$\checkmark \quad$ Threat of poaching

$\checkmark$ Changing employee demographics with acute shortage of skilled sales force. As there is ample opportunities in the Indian economy with a large chunk ofyoungsters being recruited by the BPO's and call centers, there is acute shortage of freshers.

$\checkmark$ Differences in work culture and values in the arena of work.

$\checkmark$ Work force diversity.

$\checkmark$ Retailers have to compete with other high growth industries like telecom, insurance and more specifically ITeS/BPO firms which look for similar skill sets like customer orientation, selling skills and communication skills. Salary levels offered in most IT companies are significantly higher and thus making it an attractive jump for front end employees in retail.

$\checkmark$ Knowledge e of the products and services can directly influence the sale in retail formats with assisted selling. Lack of competency can directly affect the stores reputation.

$\checkmark$ Stressful environment.

$\checkmark \quad$ Lack of formal retailing education. 
$\checkmark$ Most retail employees come with very minimal qualification; therefore they cannot be subjected to intense conceptual inputs or classroom inputs. On the other hand employees in retail sector cannot be spared for long hours or days for training, hence providing them effective training without hindering their work becomes a real predicament and a major challenge.

\section{Conclusion}

Employees are the most important assets for any organization. So the organization must ensure that the right person is hired for the right position at the right time and he is trained and developed properly to accomplish his job activities effectively. Employees in the retail sector are required to be trained according to the demands of the industry. Due to competitive scenario prevailing the jobs are becoming challenging and skilled workforce is required to meet the demand. The graduates and postgraduates are trained for the job and conversion for the skilled workforce. From the survey it is found that employees are job satisfied and committed to their jobs. The commitment increases the performance of their employees and hence productivity of the organization.

\section{References :}

[1]. Baatz, E.B. "CIO 100 -- Best Practices: The Chain Gang," CIO, (8:19), 1995, pp. 46-52.

[2]. Farley, G.A. "Discovering Supply Chain Management: A Roundtable Discussion," APICS -- The Performance Advantage, (7:1), 1997, pp. 38-39.

[3]. Lee, H.L. and C. Billington. "Managing Supply Chain Inventory: Pitfalls and Opportunities," Sloan Management Review, (33:3), 1992, pp. 65-73.

[4]. Lamming (1996) Lamming, R. (1996). Squaring Lean Supply with Supply Chain Management. International Journal of Operations\& Production Management, 16(2).

[5]. Lee HauL.,\& Corey Billington. (1995). The Evolution of Supply-Chain-Management Models and Practice at Hewlett-Packard. Interfaces, 25(5), 42-63.

[6]. Ben-Daya et al. (2008) Ben-Daya M., Hariga M., \&Khursheed S. N. (2008). Economic production quantity model with a shifting production rate. International Transactions in Operational Research, 15(1), 87-101.

[7]. Gunasekaran and Ngai (2005) Gunasekarana, A., \&Ngai E. W. T. (2005).Build-to-Order Supply Chain Management: Literature Review and Framework for Development. Journal of Operations Management, 23(5), 423-451.

[8]. Grant, D., Lambert, D., Stock, J., \&Ellram, L. ((2006). Fundamentals of Logistics Management, European Edn. Berkshire: McGraw-Hill Book Co.

[9]. Balakrishnan and Cheng (2005) Balakrishnan J., \& Cheng, C. H. (2005). The theory of constraints and the make-or-buy decision: an update and review. The Journal of Supply Chain Management, 41(1), 40-47.

[10]. NagarajanM.,\&Sobie G. (2004). Stable Far sighted Coalitions in Competitive Markets. MANAGEMENT SCIENCE, 53(1), $29-45$.

[11]. Ellram, L.M. "Supply Chain Management: The Industrial Organization Perspective," International Journal of Physical Distribution and Logistics Management, (21:1), 1991, pp. 13-22.

[12]. Giunipero, Larry C., Hooker, Robert E., Joseph-Matthews, Sacha; Yoon, Tom E., \&Brudvig, Susan (2008),”Adecade of SCM literature: past, present and future implications. Journal of Supply Chain Management, 144(4),

[13]. Simchi-Levi, D., Kaminsky, P., \&Simchi-Levi, E. (2003). Designing and Managing the supply chain Concepts,Strategies and Case studies. New York: McGraw-Hill Publishing.

[14]. Swapna Pradhan (2009), "Retailing Management, Text \& Cases", Tata McGraw Hill, New Delhi.

[15]. Srivastava, R.K. (2008) "Changing retail scene in India", International Journal of Retail and Distribution Management, Vol. 36, No 9 , pp714-721. 